\title{
Transactions
}

Cite this: Dalton Trans., 2012, 41, 11270

wWw.rsc.org/dalton

COMMUNICATION

\section{A rectangular $\mathrm{Ni}-\mathrm{Fe}$ cluster with unusual cyanide bridges $\uparrow$}

\author{
Christoph Krüger, ${ }^{a, b}$ Hiroki Sato, ${ }^{a}$ Takuto Matsumoto, ${ }^{a}$ Takuya Shiga, ${ }^{a}$ Graham N. Newton, ${ }^{a}$ Franz Renz ${ }^{b}$ \\ and Hiroki Oshio* ${ }^{a}$
}

Received 29th May 2012, Accepted 1st August 2012

DOI: $10.1039 / \mathrm{c} 2 \mathrm{dt31152f}$

An asymmetric polycyanide iron complex, $\mathrm{K}_{2}\left[\mathrm{Fe}^{\mathrm{III}}(\mathrm{L1})-\right.$ $\left.(\mathrm{CN})_{4}\right](\mathrm{MeOH})$ (HL1 = 2,2'-(1H-pyrazole-3,5-diyl)bis-pyridine), was synthesized and its complexation compatibility with nickel ions was examined. Two kinds of enantiomeric nickel-iron squares were obtained in the presence of a chiral bidentate capping ligand. The compounds display unusual cyanide bridge geometry and have ferromagnetic interactions between nickel and iron ions.

The cyanide group is a valuable unit for the construction of molecular assemblies with magnetic and electronic interactions between metal ions because it can form linear bridges between neighbouring metal centres. Cyanometallates are well known in the literature, and can form coordination bonds to transition metal ions through their terminal $\mathrm{N}$ donor atoms. ${ }^{1}$ Many examples of functional cyanide-bridged molecular assemblies have been reported. ${ }^{2}$ Indeed, molecular magnets such as singlemolecule magnets (SMMs) and single chain magnets (SCMs), the properties of which are reliant upon the interactions mediated by cyanide bridges, can be controllably constructed following modular approaches to molecular design with cyanometallate units. ${ }^{3,4}$ For example, combinations of building units with two or three free cyanide groups can often lead to the synthesis of square type $\left[\mathrm{M}_{2} \mathrm{M}_{2}^{\prime}\right]$ molecules. ${ }^{5}$ Such discrete molecules have been shown to display dynamic spin transition phenomena such as multi-spin crossover behaviour and electron-transfer-coupled spin transitions (ETCST). ${ }^{6}$ The development of new polycyano building blocks may be important for the generation of novel functional molecular systems. Therefore, we have focussed on the syntheses of polycyano iron complexes with a polynucleating ligand. In this work, the bis-bidentate ligand, 3,5-bis(2-pyridyl)pyrazolate (HL1), was chosen as the capping ligand and a novel tetracyanoferrate complex was developed. Using the tetracyano iron complex as a building block, two cyanide-bridged

${ }^{a}$ Graduate School of Pure and Applied Sciences, University of Tsukuba, Tennodai 1-1-1, Tsukuba 305-8571, Japan.

E-mail: oshio@chem.tsukuba.ac.jp; Fax:+81 29853 4238;

Tel: +81298534238

${ }^{b}$ Leibniz Universität Hannover, Institut für Anorganische Chemie,

Callinstr. 9, D-30167 Hannover, Germany

$\dagger$ Electronic supplementary information (ESI) available: Crystal structure and magnetic data of 2. CCDC 883725-883727. For ESI and crystallographic data in CIF or other electronic format see DOI: $10.1039 / \mathrm{c} 2 \mathrm{dt} 31152 \mathrm{f}$ tetranuclear nickel-iron complexes were synthesized and their magnetic properties were investigated.

The tetracyanoferrate complex, $\mathrm{K}_{2}\left[\mathrm{Fe}^{\mathrm{III}}(\mathrm{L} 1)(\mathrm{CN})_{4}\right](\mathrm{MeOH})$ $(\mathbf{1} \cdot \mathrm{MeOH})$, was synthesized by the reaction of $\mathrm{Fe}$ $\left(\mathrm{NH}_{4}\right)_{2}\left(\mathrm{SO}_{4}\right)_{2} \cdot 6 \mathrm{H}_{2} \mathrm{O}$ in boiling water with $\mathrm{HL} 1$ and $\mathrm{KCN}$.t Single crystal X-ray analysis of $\mathbf{1} \cdot \mathrm{MeOH}$ reveals that the pyrazolate group of the ligand is deprotonated and coordinates to one iron and one potassium ion which occupy the two bidentate sites of L1 (Fig. 1). The second potassium ion connects neighbouring complexes through the $\mathrm{CN}$ groups. 1 forms a one-dimensional network structure linked by potassium ions. $\S$ The combination of the tetracyanoferrate complex 1 with $\mathrm{NiCl}_{2} \cdot 6 \mathrm{H}_{2} \mathrm{O}$ and the
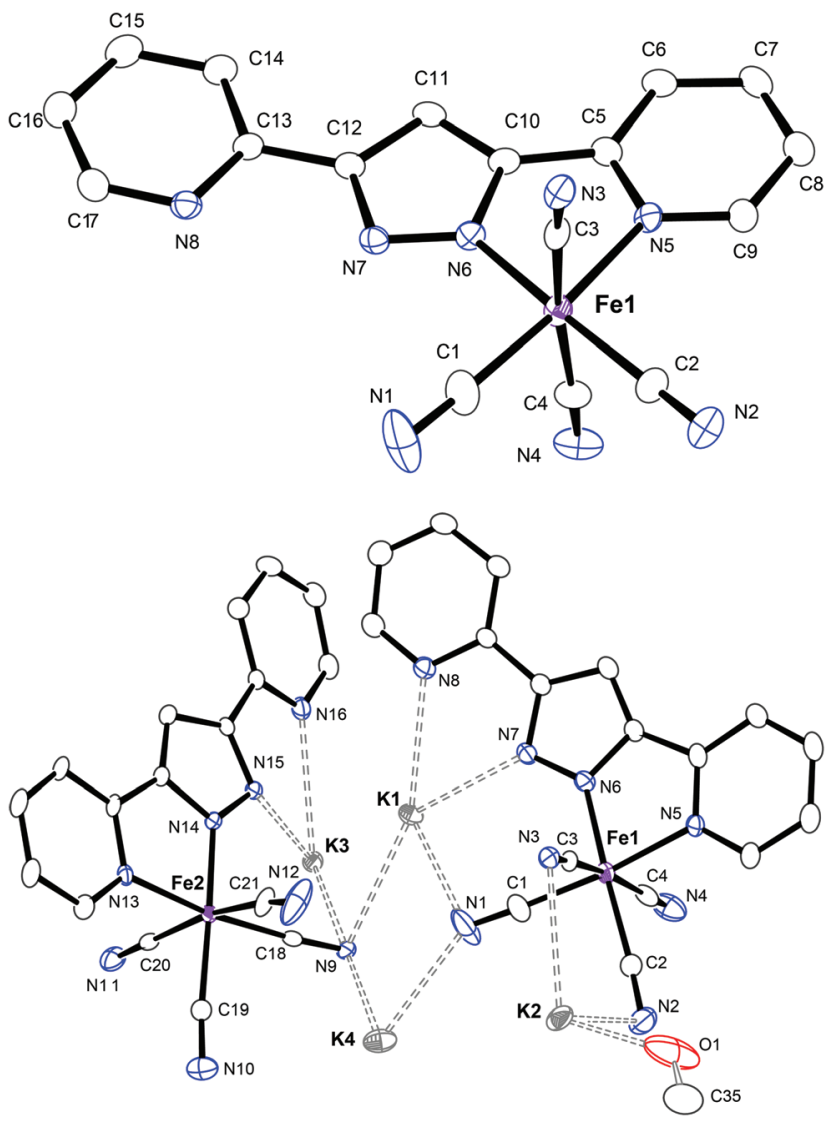

Fig. 1 Molecular structure of 1. (top) Tetracyanoferrate moiety, (bottom) asymmetric unit. Fe centres in purple; $\mathrm{K}$ grey; $\mathrm{N}$ blue; $\mathrm{O}$ red; $\mathrm{C}$ white. Lattice solvent molecules were excluded for clarity. 
chiral bidentate ligand $\mathrm{L} 2^{R}$ (L2 ${ }^{R}=N$-(2-pyridylmethylene)-(R)1-phenylethylamine) yielded a tetranuclear heterometallic complex, $\left\{\left[\mathrm{Ni}\left(\mathrm{L} 2^{R}\right)\right]_{2}\left[\mathrm{Fe}(\mathrm{L} 1)(\mathrm{CN})_{4}\right]_{2}\right\} \cdot 6 \mathrm{H}_{2} \mathrm{O} \cdot 2 \mathrm{MeOH}\left(2 \cdot 6 \mathrm{H}_{2} \mathrm{O}\right.$. $2 \mathrm{MeOH})$. The corresponding enantiomer 3 was prepared by the same method using $\mathrm{L}_{2}{ }^{S}$ (L2 ${ }^{S}=N$-(2-pyridylmethylene)-(S)1-phenylethylamine).

$\mathrm{X}$-ray structural analysis revealed that $\mathbf{2}$ and $\mathbf{3}$ were enantiomers. Complex 3 comprises two nickel ions, two chiral ligands and two tetracyanoferrate moieties, forming rectangular molecules with $\mathrm{Ni}-\mathrm{NC}-\mathrm{Fe}$ bridges, with the complex molecule located on a two-fold axis of symmetry. The nickel ion has an octahedral $\mathrm{N}_{6}$ coordination geometry with donor atoms from the bidentate chiral ligand, the bidentate site of $\mathbf{1}$ and two cyanide groups, also from $\mathbf{1}$. Thus the building unit, $\mathbf{1}$, behaves simultaneously as a tridentate capping group and as a bridging ligand. Two nitrogen atoms (N9 and N10) of the supporting chiral ligand coordinate to the Nil atom, along with three nitrogen atoms (N1, N7, and N8) from 1, in which the N7 and N8 donor atoms belong to the bidentate site of L1. Interestingly, the cyanide nitrogen atom $\mathrm{N} 1$ bridges between $\mathrm{Ni}$ and $\mathrm{Fe}$ ions in an unusual manner: with an (Ni1-N1-C1) angle of $105.0(3)^{\circ}$ in 2 and $104.8(3)^{\circ}$ in 3 . To the best of our knowledge, the sharpest $\mathrm{Ni}-\mathrm{N} \equiv \mathrm{C}$ angle reported in a cyanide-bridged square complex is $147.8(2)^{\circ},{ }^{7}$ while the sharpest reported in any species was in a dinuclear nickel complex displaying coordination angles of $111.2-112.9^{\circ}{ }^{8}$ The presented compounds thus contain the most acute $\mathrm{Ni}-\mathrm{N} \equiv \mathrm{C}$ angles observed to date (Fig. 2).

Magnetic susceptibility data for $\mathbf{2} \cdot 11 \mathrm{H}_{2} \mathrm{O}$ and $\mathbf{3} \cdot 11 \mathrm{H}_{2} \mathrm{O}$ were collected in the temperature range of $1.8-300 \mathrm{~K}$ under an applied magnetic field of 500 Oe (Fig. 3 and S2 $\dagger$ ). The $\chi_{\mathrm{m}} T$ value for 3 was $3.43 \mathrm{emu} \mathrm{mol}^{-1} \mathrm{~K}$ at $300 \mathrm{~K}$, larger than the value $\left(2.75 \mathrm{emu} \mathrm{mol}^{-1} \mathrm{~K}\right)$ expected for the sum of the uncorrelated spins of two Ni(II) ions and two Fe(III) ions. These discrepancies are explained by the large $g$ values of the nickel and iron ions. ${ }^{9}$ As the temperature was lowered, the $\chi_{\mathrm{m}} T$ value of $\mathbf{3}$ increased, reaching a maximum of $5.04 \mathrm{emu} \mathrm{mol}^{-1} \mathrm{~K}$ at $9.0 \mathrm{~K}$, followed by a steep decrease to $4.24 \mathrm{emu} \mathrm{mol}^{-1} \mathrm{~K}$ at $1.8 \mathrm{~K}$. The temperature dependence of the magnetic susceptibility data suggests that ferromagnetic interactions between nickel and iron ions are operative through the cyanide and pyrazolate bridges. The magnetic behaviour was analyzed for both samples with a Heisenberg spin model of $\boldsymbol{H}=-2 J_{1} \boldsymbol{S}_{\mathrm{Fe} 1}\left(\boldsymbol{S}_{\mathrm{Ni} 1}+\boldsymbol{S}_{\mathrm{Ni1} 1^{*}}\right)-$ $2 J_{2} \boldsymbol{S}_{\mathrm{Fe} 1 *}\left(\boldsymbol{S}_{\mathrm{Ni1}}+\boldsymbol{S}_{\mathrm{Ni} 1 *}\right)$ for the data above $10 \mathrm{~K}$, using julX. ${ }^{10}$ In this simulation, intermolecular interactions based on a molecular field approximation $z J^{\prime}\left(\chi=\chi_{0} /\left[1-\chi_{0}\left(2 z J^{\prime} / N g^{2} \mu_{\mathrm{B}}^{2}\right)\right]\right)$ were considered. The obtained best fit parameters for $\mathbf{2}$ and $\mathbf{3}$ were $g_{\mathrm{Fe}}=2.31,2.31, g_{\mathrm{Ni}}=2.18,2.10, J_{1}=+7.2,+7.0 \mathrm{~cm}^{-1}$, $J_{2}=+4.2,+4.0 \mathrm{~cm}^{-1}$, and $z J^{\prime}=-1.5 \mathrm{~K},-1.7 \mathrm{~K}$, respectively. The $z J^{\prime}$ parameters imply intermolecular magnetic interactions, but also include contributions from the magnetic anisotropy present in the system. The ferromagnetic arrangement of the spins leads to a spin ground state of $S_{\mathrm{T}}=3$. Neither $\mathbf{2}$ nor $\mathbf{3}$ showed any out of phase response in their ac magnetic susceptibility, suggesting they were not SMMs.

We synthesised a novel tetracyanoferrate building unit, using which two heterometallic nickel-iron rectangular complexes were obtained. The orientation of the cyanide group on the iron site led to very unusual $\mathrm{Ni}-\mathrm{N} \equiv \mathrm{C}$ bonding angles in $\mathbf{2}$ and $\mathbf{3}$. The investigation into the coordination behaviour of $\mathbf{1}$ showed

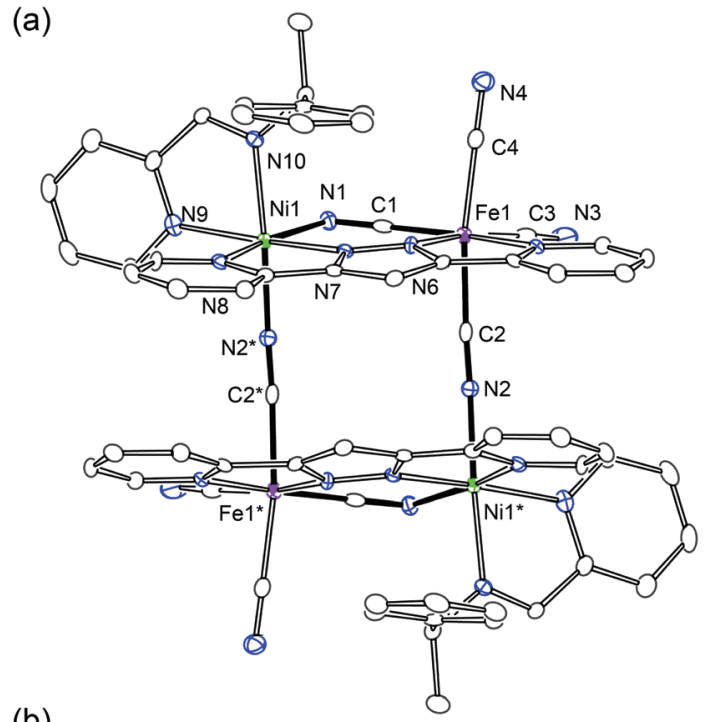

(b)

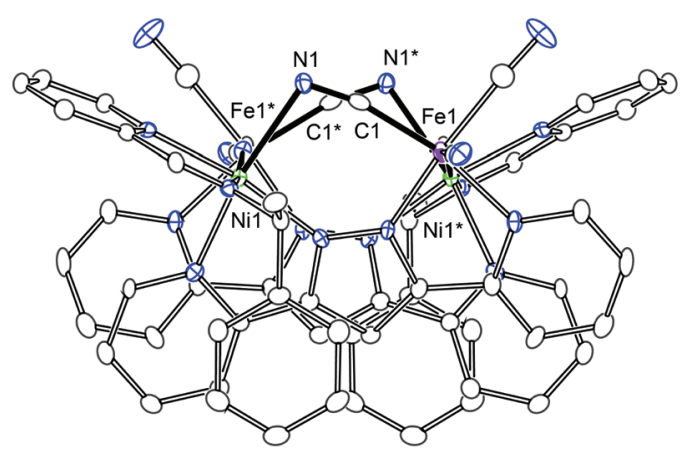

Fig. 2 ORTEP diagrams of complex 3. (a) Top view, (b) side view. Selected bond angles: Ni1-N1-C1 104.8(3), Ni1*-N2-C2 170.2(4) (symmetry code: $*,-x+1,-y+1, z$ ).

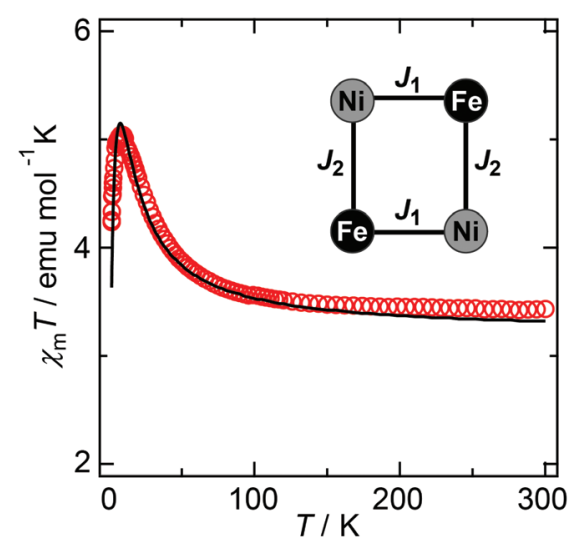

Fig. $3 \chi_{\mathrm{m}} T$ versus $T$ plots for 3 . The solid line indicates the theoretical value (see text).

that it tends to coordinate metal ions in a tridentate manner by adding a cyanide donor to the typically bidentate pyrazolepyridine binding site, and can bridge to additional metal ions via its free cyanide groups. It is expected that $\mathbf{1}$ may be used to generate magnetic one-dimensional networks due to its charge of -2 and its four perpendicular cyanide ligands. This work will be 
extended to investigate the combination of $\mathbf{1}$ with other transition metals and supporting ligands.

We gratefully acknowledge a Grant-in-Aid for Scientific Research and for Priority Area "Coordination Programming" (area 2107) from the MEXT of Japan.

\section{Notes and references}

$+\mathrm{K}_{2}\left[\mathrm{Fe}^{\mathrm{III}}(\mathrm{L} 1)(\mathrm{CN})_{4}\right](\mathrm{MeOH})(\mathbf{1} \cdot \mathrm{MeOH})$ : To a suspension of HL1 (3.8 g, $17 \mathrm{mmol})$ in boiling water $\left(100 \mathrm{~cm}^{3}\right), \mathrm{Fe}\left(\mathrm{NH}_{4}\right)_{2}\left(\mathrm{SO}_{4}\right)_{2} \cdot 6 \mathrm{H}_{2} \mathrm{O}(3.9 \mathrm{~g}$, $10 \mathrm{mmol}$ ) was added. After stirring for a few minutes, a large excess of $\mathrm{KCN}(9.77 \mathrm{mg}, 150 \mathrm{mmol}$ ) was added as a solid to the resultant dark red mixture. After boiling and stirring for a few minutes, the reaction mixture was filtered. The orange filtrate was cooled down to r.t. and left to stand for one day, after which time unreacted ligands had precipitated. The mixture was filtered again and left to stand undisturbed. After a few days, yellow microcrystals of the crude product were obtained. The yellow microcrystals were re-crystallized from methanol $/ n$-butanol to afford purple needle crystals of $\left[\left\{\mathrm{K}_{2} \mathrm{Fe}^{\mathrm{III}}(\mathrm{L} 1)(\mathrm{CN})_{4}\right\}_{2}(\mathrm{MeOH})\right] \cdot \mathrm{MeOH}$ (1. $\mathrm{MeOH})$. Anal. calcd for $1 \cdot \mathrm{MeOH} \mathrm{C}_{18} \mathrm{H}_{13} \mathrm{~N}_{8} \mathrm{FeK}_{2} \mathrm{O}_{1}$ : C, 44.00; $\mathrm{H}, 2.67 ; \mathrm{N}, 22.80$. Found: $\mathrm{C}, 43.71 ; \mathrm{H}, 2.58 ; \mathrm{N}, 22.70 \%$.

$\left\{\left[\mathrm{Ni}\left(\mathrm{L} 2^{R}\right)\right]_{2}\left[\mathrm{Fe}(\mathrm{L} 1)(\mathrm{CN})_{4}\right]_{2}\right\} \cdot 11 \mathrm{H}_{2} \mathrm{O}\left(2 \cdot 11 \mathrm{H}_{2} \mathrm{O}\right)$ : To an aqueous solution $\left(5 \mathrm{~cm}^{3}\right)$ of $1(31.88 \mathrm{mg}, 0.06 \mathrm{mmol})$ was added a mixture of $\mathrm{NiCl}_{2} \cdot 6 \mathrm{H}_{2} \mathrm{O}(14.26 \mathrm{mg}, 0.06 \mathrm{mmol}), 2$-pyridine carbaldehyde $(5.7 \mu \mathrm{L}$, $0.06 \mathrm{mmol})$ and $R$-phenylethylamine $(7.6 \mu \mathrm{L}, 0.06 \mathrm{mmol})$ in methanol $\left(5 \mathrm{~cm}^{3}\right)$. After stirring for a few seconds, the resulting solution was filtered and left for a few days after which purple crystals were obtained. The crystals were filtered and recrystallized from methanol yielding purple platelet crystals of $\left\{\left[\mathrm{Ni}\left(\mathrm{L} 2^{R}\right)\right]_{2}\left[\mathrm{Fe}(\mathrm{L} 1)(\mathrm{CN})_{4}\right]_{2}\right\} \cdot 6 \mathrm{H}_{2} \mathrm{O} \cdot 2 \mathrm{MeOH}$ $\left(2 \cdot 6 \mathrm{H}_{2} \mathrm{O} \cdot 2 \mathrm{MeOH}\right)$. They were collected by suction filtration and dried in air. Anal. calcd for $2 \cdot 11 \mathrm{H}_{2} \mathrm{O} \mathrm{C}{ }_{62} \mathrm{H}_{88} \mathrm{~N}_{20} \mathrm{Ni}_{2} \mathrm{Fe}_{2} \mathrm{O}_{11}$ : C, 49.70; H, 4.57; $\mathrm{N}, 18.70$. Found: C, 49.79; H, 4.43; N, 18.57\%.

$\left\{\left[\mathrm{Ni}\left(\mathrm{L} 2^{S}\right)\right]_{2}\left[\mathrm{Fe}(\mathrm{L} 1)(\mathrm{CN})_{4}\right]_{2}\right\} \cdot 11 \mathrm{H}_{2} \mathrm{O} \quad\left(\mathbf{3} \cdot 11 \mathrm{H}_{2} \mathrm{O}\right)$ : Complex $\mathbf{3} \cdot 11 \mathrm{H}_{2} \mathrm{O}$ was prepared by the same method as 2, using $S$-phenylethylamine. Anal. calcd for $3 \cdot 11 \mathrm{H}_{2} \mathrm{O} \mathrm{C}{ }_{62} \mathrm{H}_{88} \mathrm{~N}_{20} \mathrm{Ni}_{2} \mathrm{Fe}_{2} \mathrm{O}_{11}$ : C, 49.70; H, 4.57; N, 18.70 . Found: C, 50.00; H, 4.50; N, 18.53\%.

$\S$ Crystal data for 1: $\mathrm{C}_{36} \mathrm{H}_{26} \mathrm{~N}_{16} \mathrm{Fe}_{2} \mathrm{~K}_{4} \mathrm{O}_{2}, M_{\mathrm{r}}=982.83$, monoclinic, $P 2_{1} / c$, $a=8.408(4), b=20.572(10), c=24.726(13) \AA, \beta=99.789(7), V=$ 4215(4) $\AA^{3}, Z=4, d=1.549 \mathrm{~g} \mathrm{~cm}^{-1}, \mu=1.138 \mathrm{~mm}^{-1}, F(000)=1992$, $\mathrm{GOF}=0.954$. A total of 25983 reflections were collected, 9551 of which were unique $\left(R_{\text {(int) }}=0.1217\right) . R_{1}\left(\mathrm{w} R_{2}\right)=0.0740(0.1833)$ for 563 parameters and 9551 reflections $(I>2 \sigma(I))$. Crystal data for 2.6 $\mathrm{H}_{2} \mathrm{O} \cdot 2 \mathrm{MeOH}: \mathrm{C}_{64} \mathrm{H}_{46} \mathrm{~N}_{20} \mathrm{Ni}_{2} \mathrm{Fe}_{2} \mathrm{O}_{8}, M_{\mathrm{r}}=1452.33$, orthorhombic, $P 2{ }_{1} 2{ }_{1} 2, a=13.334(2), b=20.437(3), c=11.9421(18) \AA, V=3254.5(9)$ $\AA^{3}, Z=2, d=1.482 \mathrm{~g} \mathrm{~cm}^{-1}, \mu=1.078 \mathrm{~mm}^{-1}, F(000)=1484, \mathrm{GOF}=$ 1.043 , Flack parameter of $x=-0.004(14)$. A total of 18523 reflections were collected, 7251 of which were unique $\left(R_{\text {(int) }}=0.0412\right) . R_{1}\left(\mathrm{w} R_{2}\right)=$ $0.0395(0.0979)$ for 444 parameters and 7251 reflections $(I>2 \sigma(I))$. Crystal data for $3 \cdot 6 \mathrm{H}_{2} \mathrm{O} \cdot 2 \mathrm{MeOH}: \mathrm{C}_{64} \mathrm{H}_{44} \mathrm{~N}_{20} \mathrm{Ni}_{2} \mathrm{Fe}_{2} \mathrm{O}_{8}, M_{\mathrm{r}}=1450.31$, orthorhombic, $P 2{ }_{1} 2{ }_{1} 2, a=13.319(2), b=20.390(3), c=11.9344(18) \AA$, $V=3241.0(8) \AA^{3}, Z=2, d=1.486 \mathrm{~g} \mathrm{~cm}^{-1}, \mu=1.082 \mathrm{~mm}^{-1}, F(000)=$ $1480, \mathrm{GOF}=1.002$, Flack parameter of $x=-0.017(15)$. A total of 20217 reflections were collected, 7363 of which were unique $\left(R_{\text {(int) }}=\right.$ $0.0511) . R_{1}\left(\mathrm{w} R_{2}\right)=0.0498(0.1003)$ for 444 parameters and 7363 reflections $(I>2 \sigma(I))$. The intensity data were collected on a Bruker SMART APEX diffractometer with graphite-monochromated Mo $\mathrm{K} \alpha$ radiation $(\lambda=0.71073 \AA)$. Direct methods were used to solve the structure and to locate the heavy atoms using the SHELXL-97 program package. The remaining atoms were found from successive full-matrix least-squares refinements on $F^{2}$ and Fourier syntheses. Routine Lorentz polarization corrections and an absorption correction were applied. CCDC 883725-883727 for $\mathbf{1 - 3}$, respectively.

1 W. P. Griffith, Coord. Chem. Rev., 1975, 17, 177-247; K. R. Dunbar and R. A. Heintz, Prog. Inorg. Chem., 1997, 45, 283-391 and references cited therein; M. Verdaguer, A. Bleuzen, V. Marvaud, J. Vaissermann, M. Seuleima, C. Desplanches, A. Scuiller, C. Train, R. Garde, G. Gelly, C. Lomenech, I. Rosenman, P. Veillet, C. Cartier and F. Villain, Coord. Chem. Rev., 1999, 190-192, 1023-1047, and references cited therein; M. Verdaguer, Science, 1996, 272, 698-699.
2 W. Kosaka, K. Nomura, K. Hashimoto and S. Ohkoshi, J. Am. Chem. Soc., 2005, 127, 8590-8591; W. E. Buschmann, J. Ensling, P. Gütlich and J. S. Miller, Chem.-Eur. J., 1999, 5, 3019-3028; S. Ohkoshi, H. Tokoro, T. Matsuda, H. Takahashi, H. Irie and K. Hashimoto, Angew. Chem., Int. Ed., 2007, 46, 3238-3241; S. Ohkoshi, A. Fujishima and K. Hashimoto, J. Am. Chem. Soc., 1998, 120, 5349-5350; S. S. Kaye and J. R. Long, J. Am. Chem. Soc., 2005, 127, 6506-6507.

3 P. Gütlich, Y. Garcia and T. Woike, Coord. Chem. Rev., 2001, 219, 839879; T. Mallah, S. Thiébaut, M. Verdaguer and P. Veillet, Science, 1993, 262, 1554-1557; S. Ferlay, T. Mallah, R. Ouahès, P. Veillet and M. Verdaguer, Nature, 1995, 378, 701-703; W. R. Entley and G. S. Girolami, Science, 1995, 268, 397-400; S. Ohkoshi, A. Fujishima and K. Hashimoto, J. Am. Chem. Soc., 1998, 120, 5349-5350; Ø. Hatlevik, W. E. Buschmann, J. Zhang, J. L. Manson and J. S. Miller, Adv. Mater., 1999, 11, 914-918; S. M. Holmes and G. S. Girolami, J. Am. Chem. Soc., 1999, 121, 5593-5594; S. Ohkoshi, M. Mizuno, G. J. Hung and K. Hashimoto, J. Phys. Chem. B, 2000, 104, 9365-9367; R. Garde, F. Villain and M. Verdaguer, J. Am. Chem. Soc., 2002, 124, 10531-10538; E. Coronado, M. C. Giménez-López, G. Levchenko, F. M. Romero, V. García-Baonza, A. Milner and M. Paz-Pasternak, J. Am. Chem. Soc., 2005, 127, 4580-4581; C. Avendano, M. G. Hilfiger, A. Prosvirin, C. Sanders, D. Stepien and K. R. Dunbar, J. Am. Chem. Soc., 2010, 132, 13123-13125; R. Boča, I. Šalitroš, J. Kožíšek, J. Linares, J. Moncol and F. Renz, Dalton Trans., 2010, 39, 2198-2200.

4 D. Li, S. Parkin, G. Wang, G. T. Yee, A. V. Prosvirin and S. M. Holmes, Inorg. Chem., 2005, 44, 4903-4905; W. Liu, C.-F. Wang, Y.-Z. Li, J.-L. Zuo and X.-Z. You, Inorg. Chem., 2006, 45, 10058-10065; D. Li, R. Clérac, G. Wang, G. T. Yee and S. M. Holmes, Eur. J. Inorg. Chem., 2007, 1341-1346; C.-F. Wang, W. Liu, Y. Song, X.-H. Zhou, J.-L. Zuo and X.-Z. You, Eur. J. Inorg. Chem., 2008, 717-727; D. Wu, Y. Zhang, W. Huanga and O. Sato, Dalton Trans., 2010, 39, 5500-5503; Y.-H. Peng, Y.-F. Meng, L. Hu, Q.-X. Li, Y.-Z. Li, J.-L. Zuo and X.-Z. You, Inorg. Chem., 2010, 49, 1905-1912; N. Hoshino, Y. Sekine, M. Nihei and H. Oshio, Chem. Commun., 2010, 46, 6117-6119; K. Park and S. M. Holmes, Phys. Rev. B, 2006, 74, 224440-1-10.

5 G. N. Newton, M. Nihei and H. Oshio, Eur. J. Inorg. Chem., 2011, 20, 3019-3224, and references cited therein.

6 M. Nihei, M. Ui, M. Yokota, L. Han, A. Maeda, H. Kishida, H. Okamoto and H. Oshio, Angew. Chem., Int. Ed., 2005, 44, 6484-6487; M. Nihei, M. Ui and H. Oshio, Polyhedron, 2009, 28, 1718-1721; I. Boldog, F. J. Muñoz-Lara, A. B. Gaspar, M. C. Muñoz, M. Seredyuk and J. A. Real, Inorg. Chem., 2009, 48, 3710-3719; A. Rodríguez-Diéguez, R. Kivekäs, R. Sillanpä, J. Cano, F. Lloret, V. McKee, H. Stoeckli-Evans and E. Colacio, Inorg. Chem., 2006, 45, 10537-10551; C. P. Berlinguette, A. Dragulescu-Andrasi, A. Sieber, J. R. GalánMascarós, H. U. Güdel, C. Achim and K. R. Dunbar, J. Am. Chem. Soc., 2004, 126, 6222-6223; C. P. Berlinguette, A. Dragulescu-Andrasi, A. Sieber, H. U. Güdel, C. Achim and K. R. Dunbar, J. Am. Chem. Soc., 2005, 127, 6766-6779; M. Shatruk, A. Dragulescu-Andrasi, K. E. Chambers, S. A. Stoian, E. L. Bominaar, C. Achim and K. R. Dunbar, J. Am. Chem. Soc., 2007, 129, 6104-6116; M. G. Hilfiger, M. Chen, T. V. Brinzari, T. M. Nocera, M. Shatruk, D. T. Petasis, J. L. Musfeldt, C. Achim and K. R. Dunbar, Angew. Chem., Int. Ed., 2010, 49, 1410-1413; D. Li, R. Clérac, O. Roubeau, E. Harté, C. Mathonière, R. Le Bris and S. M. Holmes, J. Am. Chem. Soc., 2008, 130, 252-258; Y. Zhang, D. Li, R. Clérac, M. Kalisz, C. Mathonière and S. M. Holmes, Angew. Chem., Int. Ed., 2010, 49, 3752-3756; M. Nihei, Y. Sekine, N. Suganami and H. Oshio, Chem. Lett., 2010, 39, 978-979; M. Nihei, Y. Sekine, N. Suganami, K. Nakazawa, A. Nakao, H. Nakao, Y. Murakami and H. Oshio, J. Am. Chem. Soc., 2011, 133, 3592-3600; J. Mercurol, Y. Li, E. Pardo, O. Risset, M. Seuleiman, H. Rousselière, R. Lescouëzec and M. Julve, Chem. Commun., 2010, 46, 8995-8997.

7 L. Jiang, T.-B. Lu and X.-L. Feng, Inorg. Chem., 2005, 44, 7056-7062.

8 F. Meyer, R. F. Winter and E. Kaifer, Inorg. Chem., 2001, 40, 45974603.

9 E. A. Boudreaux and L. N. Mulay, Theory and Application of Molecular Paramagnetism, John Wiley \& Sons, Inc., New York, 1976, 491; R. Boča, Struct. Bonding, 2006, 117, 1-264; R. L. Carlin, Magnetochemistry, Springer-Verlag, Berlin Heidelberg, 1986.

10 The program julX written by E. Bill was used for the simulation and analysis of magnetic susceptibility data. http://ewww.mpi-muelheim.mpg. de/bac/logins/bill/julX_en.php 